\title{
Fimbriaria fasciolaris and Cloacotaenia megalops (Eucestoda, Hymenolepididae), Cestodes from Brazilian Waterfowl
}

\author{
Luís C Muniz-Pereira/ ${ }^{+}$, Suzana B Amato*
}

Laboratório de Helmintos Parasitos de Vertebrados, Departamento de Helmintologia, Instituto Oswaldo Cruz, Av. Brasil 4365, 21045-900 Rio de Janeiro, RJ, Brasil *Departamento de Biologia Animal, Universidade Federal Rural do Rio de Janeiro, Caixa Postal 74512, 23851-970 Seropédica, RJ, Brasil

Two cestode species, Fimbriaria fasciolaris (Pallas, 1781) Frölich, 1802 Cloacotaenia megalops (Nitzsch in Creplin, 1829) Wolffhügel,1938 collected from Anas bahamensis Linné, 1758 and Amazonetta brasiliensis (Gmelin, 1758) in lagoons of the Maricá District, State of Rio de Janeiro, Brazil, are described. This is the first record of F. fasciolaris parasitizing A. bahamensis. The prevalence, intensity of infection, and mean intensity of infection for both species are given. Overdispersion distribution is reported for $\mathrm{F}$. fasciolaris with 535 specimens collected in a single A. bahamensis. A key for the genera in the Fimbriariinae is presented. Anatomical features of $\mathrm{F}$. fasciolaris and C. megalops are discussed.

Key words: Fimbriaria fasciolaris - Cloacotaenia megalops - Anatidae - key characters - overdispersion distribution - Brazil

The present work is the third of a series (MunizPereira \& Amato 1993, 1995) related to a survey of helminths parasitizing two species of Brazilian waterfowls, Anas bahamensis Linné, 1758 and Amazonetta braziliensis (Gmelin, 1758). This series is scheduled to fulfil a broad field in Brazilian helminthology, started by Natterer, the 19th century Austrian naturalist, who capturing vertebrates, mainly mammals (12,293 specimens) and birds (1,146 specimens), also collected their parasites (2,000 samples). This parasites were later studied by outstanding helminthologists, such as Rudolphi, Diesing, Fuhrmann, Wolffhügel, Braun, among others. One of the first Brazilian helminthologists to make reference to waterfowl parasites was Magalhães (1899), who recorded digeneans and nematodes from ducks, collected by Natterer in the State of Rio de Janeiro. Subsequent papers on parasites of Brazilian waterfowl are non-periodical and the information is fragmentary, neither focusing on extensive surveys nor based on a specific group of avian host.

\footnotetext{
Supported by CNPq, Capes.

${ }^{+}$Corresponding author. E-mail:1muniz@ netgate.com.br

* Research Fellow CNPq. E-mail: sbamato@ rio.com.br. Received 4 March 1998

Accepted 17 August 1998
}

\section{MATERIALS AND METHODS}

The birds, 18 Anas bahamensis (L.) and 22 Amazonetta brasiliensis (Gmelin), and the helminths were collected as reported earlier (MunizPereira \& Amato 1993, 1995) at Maricá and Guarapina Lagoons, in Maricá District, State of Rio de Janeiro, Brazil. Birds were deposited as symbiotypes voucher specimens, sensu Brooks (1993), in the Ornithological Collection of the Museu Nacional do Rio de Janeiro. Histological sections were prepared following Luna (1968), stained with hematoxylin-eosin and mounted in Canada balsam. The terms prevalence, mean intensity of infection, and site of infection are used according to Margolis et al. (1982). Measurements are in micrometers, unless otherwise stated; the number inside parentheses is the mean value, and " $\mathrm{n}$ " is the number of specimens measured. Photomicrographs were obtained in a Zeiss mod. Axiophoto system. Voucher specimens were deposited in the Helminthological Collection of the Instituto Oswaldo Cruz (CHIOC), Rio de Janeiro, RJ, Brazil.

\section{DESCRIPTIONS}

\section{Fimbriaria fasciolaris (Pallas, 1781) Frölich, 1802 (Figs 1-2)}

Description of studied specimen (based on 15 specimens mounted in toto, 15 measured and 136 histological sections): Hymenolepididae, Fimbriariinae: strobila internally and externally segmented, losing segmentation at the posterior end, 3.5 -104 mm (29.8 mm) long, 0.458-1.67 mm 
(0.776) greatest width; calcareous corpuscules conspicuous. Scolex, $18.3(\mathrm{n}=1)$ long, $58.6(\mathrm{n}=1)$ wide; four unarmed suckers, round to slightly oval, 38.4 $(\mathrm{n}=1)$ long, $34.8(\mathrm{n}=1)$ wide; rostelum armed with a single circle of ten hooks, $60.4(\mathrm{n}=1)$ long, 32.9 $(\mathrm{n}=1)$ wide; pseudoescolex triangular, conspicuous, no genital primordia present, with segmention visible, becoming leaflike when mature, 586-970 (787) $(n=12)$ wide; neck zone following as a continuation of pseudoescolex. Six osmoregulatory canals, joined in three pairs, 14.6-36.5 (30.8) $(n=9)$ wide. Longitudinal muscular system with single circle of 67-105 bundles, 14.7-23.8 (19.6) in diameter.

Male reproductive system: testes spherical to oval, often in number of three per cirrus pouch, 36.5-95 ( $\mathrm{n}=8)$ long, 21.9-51 (39.7) $(\mathrm{n}=7)$ wide; external seminal vesicle present; cirrus pouch clubshaped, 56.8-82.4 (66.7) $(\mathrm{n}=5)$ long, 9.2-16.5 $(12.8)(n=5)$ wide: internal seminal vesicle poorly developed; cirrus with minute spines.

Female reproductive system: ovary transversely elongate, non-metameric; seminal receptacle spherical; vagina narrow, elongate; uterus reticulate non-metameric, numerous eggs released in short strings when mature; oncospheres, 16.5-23.8 (18.1) $(\mathrm{n}=10)$ in diameter, hooklets not seen; genital atrium, 12.8-14.6 (13.4) wide; genital pores unilateral, marginal, deeply embedded in the cortex region, apertures surrounded by very minute spines.

Taxonomic summary

Hosts: Anas bahamensis Linné, 1758, Amazonetta brasiliensis (Gmelin, 1758).

Site of infection: anterior intestine.

Locality: Lagoon of Maricá, Lagoon of Guarapina, mouth of the Mombuca river, Maricá District, State of Rio de Janeiro, Brazil.

Prevalence: A. bahamensis 55.6\%, A. brasiliensis $4.5 \%$.

Intensity of infection: A. bahamensis 2-535, Amazonetta brasiliensis 1.

Mean intensity of infection: A. bahamensis 60.8 , Amazonetta brasiliensis 1 .

Other hosts: AVES - ANSERIFORMES: Anser anser, A. anser (dom.), A. caerulescens, A. cygnoides, A. cygnoides (dom.), A. erythropus, Cygnus olor, Branta sandivicencis, Alopochen aegyptiaca, Chloephaga picta, C. poliocephala, Cyanochen cyanoptera, Lophonetta specularioides, Tadorna ferruginea, T. tadorna, Anas platyrhynchos, A. platyrhynchos (dom.), A. acuta, A. castanea, A. clypeata, A. crecca, A. discors, A. falcata, A. formosa, A. penelope, A. poecilorhyncha, A. punctata, A. querquedula, A. rubripes, A. specularis, A. strepera, A. superciliosa,
A. versicolor, Somateria fischeri, S. mollisima, $S$. spectabilis, Aythya collaris, A. affinis, A. ferina, A. fuligula, A. marila, A. nyroca, A. valisineria, Netta erythrphthalma, N. rufina, Cairina moschata (dom.), Sarkidiornis melanotos, Bucephala clangula, Clangula hyemalis, Histrionicus histrionicus, Melanitta fusca, M. nigra, M. perpicillata, Mergus albellus, M. merganser, M. serrator, Oxyura leucocephala, Aix sponsa. FALCONIFORMES: Accipter gentilis. GALLIFORMES: Francolinus pintadeanus, Gallus gallus (dom.). GRUIFORMES: Fulica atra. CHARADRIFORMES: Erolia maritima, Haematopus ostralegus, Larus canus. PICIFORMES: Dendrocopos medius.

Geographical distribution: Europe (Germany, France, England, Poland, Russia); North America (USA, Canada); Africa; Asia (India, China, Russia); Central America (Cuba); South America (Brazil).

Specimens deposited: CHIOC 33916, 33917.

Specimens studied: CHIOC 23366 from "goose"; CHIOC 10477, 10478 from Cairina moschata.

\section{REMARKS}

López-Neyra $(1931,1943)$ considered $F$. fasciolaris as a teratological form of Diorchis and Hymenolepis species, inducing to consider this parasite as a "monster"; he concluded that it was the result of super-hydration and maceration processes. López-Neyra's works unfortunately did not include histochemical nor life cycle studies, and he failed to produce a reasonable, convincing argument in support of his conclusion. After LópezNeyra (1943), methods to study the life cycle were improved (Jarecka 1958) and clearly indicated previous misinterpretations.

Fuhrmann (1932), based on personal observations and on the detailed work of Wolffhügel (1900), accepted this species as valid, because his specimens were mature and ovigerous, without any sign of maceration, and because the genera Diorchis and Fimbriaria are not closely related, as stated by Fuhrmann (1932). Fuhrmann (1932) in a final comment said: "Nous sommes dáccord que Fimbriaria est une monstruosité, mais bien des formes dans le nature sont dans le mème cas et appartiênnent tout de mème à des genres et à des espèces valables". In our work we fully agree with Fuhrmann, in opposition to López-Neyra, because in our specimens we were able to see all of the anatomical structures that are essential to distinguish Fimbriaria and Diorchis, and to add more data to the description, enlarging the diagnosis of this species.

The specimens now studied agree with the descriptions of Wolffhügel (1900), Lühe (1910), 
Fuhrmann (1914, 1932), Webster (1943), Czaplinski (1956), Beverley-Burton (1964), McLaughlin and Burt (1979), and with the generic diagnosis of Schmidt (1986), differing in some measurements probably influenced by the state of the development of the specimens. Those authors described the specimens belonging to species of Fimbriaria without external and internal segmentation. Beverley-Burton (1964) reported that the strobila were not clearly segmented. In the present work, we have actually observed, even in the histological sections, a process that generates the loss of segmentation from the immature to the mature portion of the strobila, depending on the development of the helminth. Earlier authors did not clearly describe the neck-zone as referred by Wolffhügel (1900) around the pseudoescolex, and also present in our material. The six osmoregulatory canals agree with those described by Fuhrmann (1932).

We were not able to observe the exact number of testes per proglottid, due to the loss of segmentation in fully developed specimens. Three testes per cirrus pouch were often observed and, although Fuhrmann (1914) stated that the number of testes in relation to the cirrus pouch was three or multiple of it, he also stated that when the cirrus pouch was in the growing process, six, seven or eight testes per cirrus pouch could be observed. The uterus in the specimens here considered was reticulate, in agreement with all of the authors previously cited.

The number of longitudinal muscular bundles showed great variation in our specimens, (67-105); Wolffhügel (1900) reported a similar variation, (60120). The 136 histological sections examined in the present study allowed us to conclude that the muscular bundles observed on longitudinal sections are of unequal length. Therefore according to the section depth, the number of the bundles observed transversally will be different, even in a single specimen, justifying the range of this character in the descriptions, and suggesting that this feature is not of systematic value, if a broad range is considered.

For the reasons above discussed, the key to the genera in the Fimbriariinae, as stated by Czaplinski and Vaucher (1994), has been modified as follows:

1a. Pseudoscolex well developed, leaflike in mature worms; six osmoregulatory canals, joined in three pairs .............. Fimbriaria Fröhlich, 1802 b. Pseudoscolex poorly or moderately developed

2a. Pseudoscolex moderately developed; six osmoregulatory canals joined in three pairs; accessory sac present

Fimbriasacculus Alexander \& McLaughlin, 1996 b. Pseudoscolex poorly developed; eight to eleven osmoregulatory canals . 3a. Eight osmoregulatory canals . Fimbriariella Wolffhügel, 1936 b.Nine or eleven osmoregulatory canals .....

Fimbriarioides Fuhrmann, 1932

Another genus, Profimbriaria, was erected by Wolffhügel (1936), to contain P. multicanalis (Baczynska, 1914), but considering that the scolex and pseudoscolex as well as the uterus are unknown, although eight osmoregulatory canals are present, we placed Profimbriaria as incertae sedis.

The cestode $F$. fasciolaris is recorded in $A$. bahamensis with a prevalence of $55.6 \%$ and a mean intensity of infection of $60.8 \%$, being, so far, one of the highest percentages registered. The difference in prevalence of this worm recovered either from male or female hosts was not significant in this work, although Drobney et al. (1983) recorded females and males of Aix sponsa with $22.5 \%$ and $1.3 \%$, respectively. This may be related to the different nutritional requirements of both sexes in various species of ducks, at the moment of the breeding season, as stated by Drobney et al. (1983).

Eighty-seven per cent of the recovered specimens of $F$. fasciolaris were found parasitizing a single A. bahamensis host, showing an overdispersion distribution. Drobney et al. (1983), although reporting similar results ( $84 \%$ of the worms recovered in a single host) made no comments on their findings.

Alexander and McLaughlin's (1996) report of a single duck, $A$. capensis, parasitized by 1,412 cestode specimens of Fimbriasacculus africanensis, as well as our results with 535 parasites found in a single A. bahamensis, clearly demonstrate the crowding effect phenomenon. The significant differences in prevalence among various host species as reported by Alexander and McLaughlin (1996), were observed by us: A. bahamensis with $55.6 \%$ and $4.5 \%$ for A. brasiliensis.

This is the first report of $F$. fasciolaris parasitizing A. bahamensis. The present record of $F$. fasciolaris from A. brasiliensis, since Natterer, is being published for the first time. Three samples of this species collected from an undetermined goose (1) and from Cairina moschata (2) are also deposited in the Helminthological Collection of the Oswaldo Cruz Institute (CHIOC).

Cloacotaenia megalops

(Nitzsch in Creplin, 1829) Wolffhügel, 1938 (Figs 3-5)

Description of studied specimens (based on 18 specimens mounted in toto, 6 measured): Hymenolepididae, Hymenolepidinae: yellowish when alive. Strobila 22.7-48.7 mm (32.6) $(\mathrm{n}=5)$ long. Scolex massive in vivo, almost square when 


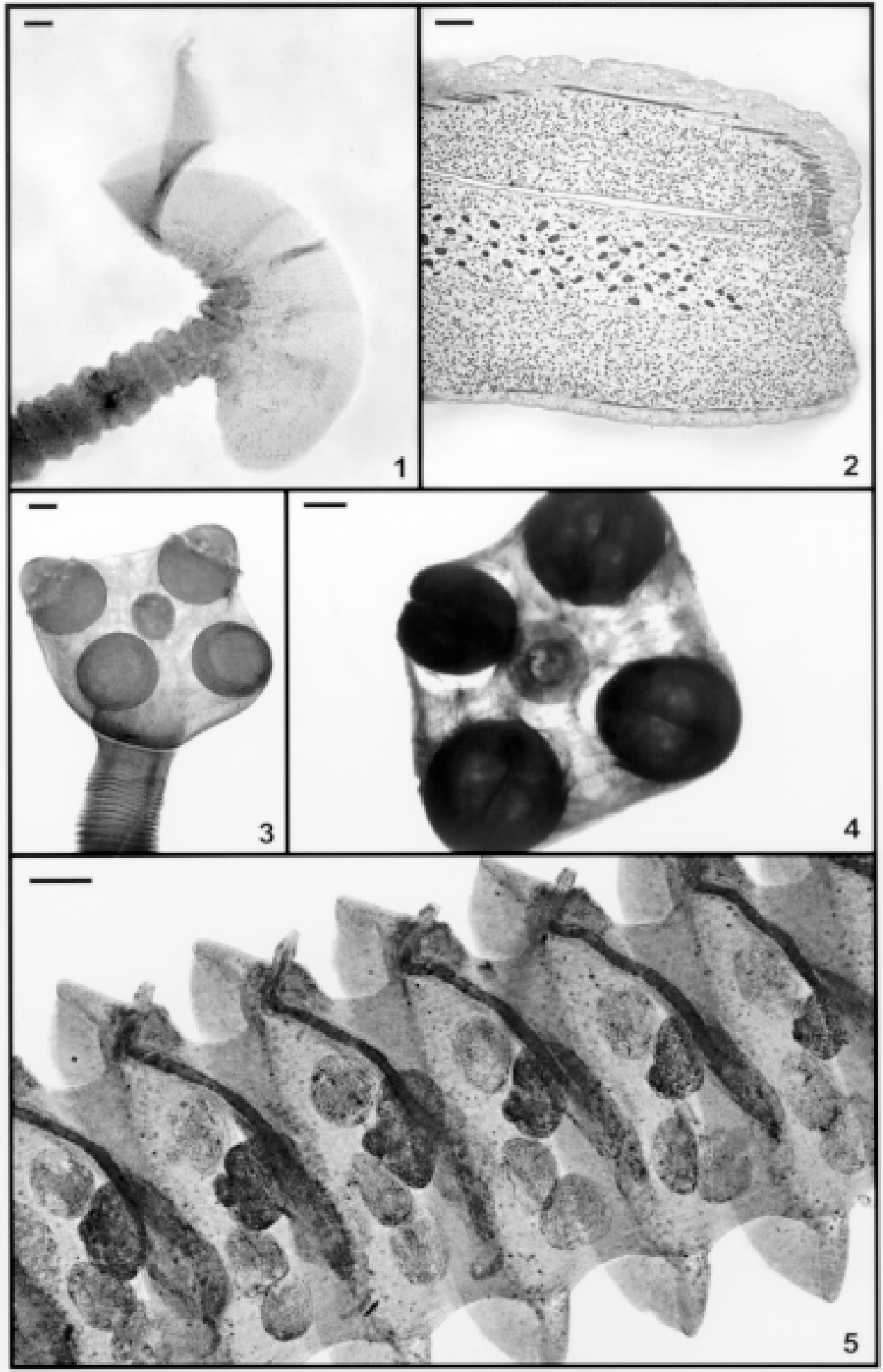

Photomicrographs of cestode specimens. Fig. 1: Fimbriaria fasciolaris (Pallas, 1781) pseudoescolex. Fig. 2: Fimbriaria fasciolaris (Pallas, 1781) longitudinal section. Fig. 3: Cloacotaenia megalops (Nitzsch in Creplin, 1829) scolex. Fig. 4: Cloacotaenia megalops (Nitzsch in Creplin, 1829) scolex en face. Fig. 5: Cloacotaenia megalops (Nitzsch in Creplin, 1829) mature proglottid. Bars - Figs $1-3=0.3 \mathrm{~mm}$; Figs $4-5=0.08 \mathrm{~mm}$. 
mounted in toto, 1.19-1.92 $\mathrm{mm}(1.59 \mathrm{~mm})$ long, $1.34-2.38 \mathrm{~mm}(1.81 \mathrm{~mm})$ wide; four muscular suckers, round, unarmed, directed forward, diameter 531-659 (604); rostellum rudimentary, unarmed; circular rostellar sac vestigial when mounted en face, elliptical in toto, 201-476 (390) long, 201476 (384) wide; neck short, 275-787 (476) long, 512-915 (705) wide; proglottids wider than long, craspedote, velum long; immature proglottid 165275 (223) long, 0.64-1.10 mm (0.86) wide; mature proglottid, 275-366 (320) long, 0.86-1.63 mm $(1.13 \mathrm{~mm})$ wide; gravid proglottids 366-549 (468) $(\mathrm{n}=5)$ long, 0.86-1.92 mm (1.29 mm) $(\mathrm{n}=5)$ wide; ventral osmoregulatory canals $27.5(\mathrm{n}=1)$ wide, 7.3 $(\mathrm{n}=1)$ wide; transversal osmoregulatory canals not observed.

Male reproductive system: three testes, spherical to ovoid, one poral, two antiporal, 102-175 (149) long, 117-183 (137) wide; external seminal vesicle present; cirrus pouch elongate, 0.59-1.02 $\mathrm{mm}$ (0.72) long; internal seminal vesicle saculiform; cirrus spined, each spine, 9.2-10.9 (9.5) long.

Female reproductive system: ovary median, transversely elongate, 95-146 (113) long, 175-241 (204) wide; vitelline gland compact, round, postovarian 44-110 (66), 51-117 (73) wide; vagina conspicuous, thin walled with spermatozoa in distal portion; seminal receptacle present; uterus saclike, in anterior portion of the proglottids, filling all space when gravid; eggs 42-46 (44) $(n=3)$ in diameter; onchosphere 18-33 (26) $(\mathrm{n}=3)$ long, 1829 (19) $(n=3)$ wide; genital atrium shallow; genital pores unilateral, dextral.

\section{Taxonomic summary}

Host: Amazonetta brasiliensis (Gmelin, 1758).

Site of infection: cloaca.

Locality: Lagoon of Maricá, Lagoon of Guarapina, mouth of the Mombuca river, Maricá District, State of Rio de Janeiro, Brazil.

Prevalence: $50 \%$.

Intensity of infection: 1-15.

Mean intensity of infection: 5.09.

Other hosts: AVES - ANSERIFORMES: Anser anser (dom.), A. caerulescens, A. brachyrhynchos, Aix sponsa, Anseranas semipalmata, Coscoroba coscoroba, Branta canadensis, Cygnus cugnus, $C$. olor, C. melanocoryphus, Lophonetta specularioides, Tadorna ferruginea, T. tadorna, Anas platyrhynchos, A. platyrhynchos (dom.), A. erythrorhyncha, A. castanea, A. acuta, A. americana, A. crecca, A. clypeata, A. cyanoptera, A. discors, A. georgica, A. penelope, A. platalea, A. rubripes, A. querquedula, A. sibilatryx, A. spinicauda, A. strepera, A. superciliosa, A. versicolor, A. bahamensis, Aythya africana, A. valisneria, A. ferina, A. fuligula, A. marila, A. nyroca, Netta erythrophthalma, N. peposaca, N. rufina, Cairina moschata, Clangula hyemalis, Melanitta fusca, Dendrocygna autumnalis, Oxyura leucocephala. GALLIFORMES: Gallus gallus (dom.). GRUIFORMES: Fulica americana.

Geographical distribution: wide geographic distribution.

Specimens deposited: CHIOC 33918, 33919.

Specimens analysed: CHIOC 30700a-b, 30706 from A. bahamensis.

\section{REMARKS}

Cloacotaenia megalops, a species of a monotypic genus, has a wide geographic distribution, parasitizes the cloaca and anus of Anseriformes, and of rarely Galliformes and Gruiformes. In relation to the taxonomic position of this species, we prefer to follow Schmidt (1986), and to consider Cloacotaenia as a valid genus. The specimens herein studied extend the range of the measurements known for this species of parasite. McLaughlin and Burt (1979) registered specimens of C. megalops with a cirrus pouch reaching 800 $\mathrm{mm}$. However, now we are dealing with specimens having cirrus pouch measuring up to $1.02 \mathrm{~mm}$ in a strobila $48.7 \mathrm{~mm}$ long, these measurements being among the greatest so far recorded for this species. In this same specimen, the greatest width of the testes was $182 \mathrm{~mm}$, while Mclaughlin and Burt (1979) registered testes with a maximum width of $180 \mathrm{~mm}$. Established differences regarding the length of the cirrus pouch and the width of the testes are related to the stage of development of the helminths, and do not justify the description of a new species.

Czaplinski (1956) and Beverley-Burton (1964) observed transversal osmoregulatory canals, the former giving no measurements, but only describing them as a thin structure, and the latter reporting a width of 2-3 $\mathrm{mm}$. The present authors and McLaughlin and Burt (1979) were unable to observe those canals. Ransom (1902) revealed the existence of a plexus in the osmoregulatory system, which has never been observed by the workers who reported on C. megalops.

Woodall (1977) collected C. megalops in Zimbabwe, and recorded it for the first from the the Ethiopian region. In Brazil, this species has been listed by Travassos (1965). Rego and Santos (1972) gave a brief account of the morphology of the specimens deposited in the CHIOC.

The high prevalence and low mean intensity of infection of C. megalops found in A. brasiliensis are the same as those recorded in the literature (Woodall 1977). Cloacotaenia megalops showed different prevalences between male (40\%) and fe- 
male $(83.3 \%)$ specimens in the hosts studied. Drobney (1980) stated that, in the period of eggsynthesis, the nutritional requirements of females are high. Drobney and Fredrickson (1979) reported that females in that period spend twice the time as do males on feeding grounds. The higher proportion of invertebrates in the diet increases the female's chances to become infected.

\section{ACKNOWLEDGMENTS}

To Prof. Jorge Bruno Nacinovic and to Prof. Dante Martins Teixeira, Seção de Ornitologia, Museu Nacional do Rio de Janeiro, Universidade Federal do Rio de Janeiro, for the capture and identification of the anatids and for accepting the birds for deposit in the Museum's Ornithological Collection, respectively; to Dr Roberto Magalhães Pinto, Departamento de Helmintologia, Instituto Oswaldo Cruz, Rio de Janeiro, for critical reading of the manuscript, and for assistance regarding photomicrographs; and to Genilton José Vieira and Marcos Gustavo Silva Ribeiro from Instituto Oswaldo Cruz for their technical help in the photomicrographs.

\section{REFERENCES}

Alexander SJ, McLaughlin JD 1996. Fimbriasacculus africanensis n. gen., n. sp. (Cestoda: Hymenolepididae) from Anas capensis, Anas undulata, and Anas erythrorhyncha (Anatidae) in South Africa. $J$ Parasitol 82: 907-909.

Beverley-Burton M 1964. Studies on the cestoda of British fresh-water birds. Proc Zool Soc London 142: 307-346.

Brooks DR 1993. Extending the symbiotype concept to host voucher specimens. J Parasitol 79: 631-633.

Czaplinski B 1956. Hymenolepididae Fuhrmann, 1907 (Cestoda) parasites of some domestic and wild Anseriformes in Poland. Acta Parasitol Pol 4: 175373.

Czaplinski B, Vaucher C 1994. Family Hymenolepididae Ariola, 1899, p. 595-663. In LF Khalil, A Jones, RA Bray (eds), CIP Keys to the Cestodes of Vertebrates, Commonwealth Agricultural Bureaux, St. Albans, UK.

Drobney RD 1980. Reproductive bioenergetics of wood duck. Auk 97: 480-490.

Drobney RD, Fredrickson LH 1979. Food selection by wood ducks in relation to breeding status. $J$ Wild Manag 43: 109-120.

Drobney RD, Train CT, Fredrickson LH 1983. Dynamics of the Platyhelminth fauna of wood duck in relation to food habitats and reproductive state. $J$ Parasitol 69: 375-380.

Fuhrmann O 1914. Sur 1'origine de Fimbriaria fasciolaris Pallas. Compte-Rendu IX Congrés Internat Zool (Monaco, 1913): 437-457.

Fuhrmann O 1932. Les ténias des oiseaux. Mém Univ Neuchâtel 8: 1-381.
Jarecka L 1958. Plankton crustaceans in the life cycle of tapeworms occurring at Druzno lake (Parasitofauna of the biocenosis of Druzno lake - Part II). Acta Parasitol Pol 6: 65-109.

López-Neyra CR 1931. La Fimbriaria fasciolaris y sus relaciones con Diorchis acuminata. Bol Univ Granada 13: 131-156.

López-Neyra CR 1943. La fimbriarización. Possibles cestodes normales que la presentan. Rev Ibér Parasitol 3: 107-140.

Lühe M 1910. Parasitische Plattwürmer. II: Cestodes. Die Süsswasserfauna Deutschlands (Brauer) 18: 1-153.

Luna LG 1968. Manual of Histologic Methods of the Armed Forces Institutes of Pathology, McGraw Hill, New York, 258 pp.

Magalhães PS 1899. Notes d'helminthologie brésiliene. 9. Monostomose suffocante des canards. Arch Parasitol 2: 258-261.

Margolis L, Esch GW, Holmes JC, Kuris AM, Schad GA 1982. The use of ecological terms in parasitology (report of an ad hoc committee of the American Society of Parasitologists). J Parasitol 68: 131133.

McLaughlin JD, Burt MDB 1979. Studies on the hymenolepidid cestodes of waterfowl from New Brunswick, Canada. Can J Zool 57: 34-79.

Muniz-Pereira LC, Amato S 1993. Philophthalmus gralli (Digenea: Philophthalmidae) parasite of Anas bahamensis and Amazonetta brasiliensis, from lagoons of Maricá county, Rio de Janeiro, Brasil. Mem Inst Oswaldo Cruz, 88: 567-569.

Muniz-Pereira LC, Amato S 1995. Natural hosts of Notocotylus breviserialis (Digenea, Notocotylidae) parasite of Brazilian waterfowl. Mem Inst Oswaldo Cruz 90: 711-714.

Ransom BH 1902. On Hymenolepis carioca (Magalhães) and H. megalops (Nitzsch) with remarks on the classification of the group. Trans Am Micr Soc 23: 151172.

Rego AA, Santos JC 1972. Cestóides de Poecilonetta bahamensis (L.) e de Cacicus haemorrhous (L.). Atas Soc Biol Rio de Janeiro 16: 31-33.

Schmidt GD 1986. Handbook of Tapeworm Identification, CRC Press, Boca Raton, Fl, 675 pp.

Travassos LP 1965. Contribuições para o inventário crítico da zoologia no Brasil, fauna helmintológica: considerações preliminares - Cestódeos. Publ Av Mus Nac 50: 1-84.

Webster JD 1943. A revision of Fimbriariinae (Cestoda, Hymenolepididae). Trans Am Micr Soc 62: 390-397.

Wolffhügel K 1900. Beitrag zur Kenntnis der Vogelhelminthen, Inaugural-Dissertation, Universität Basel, Freiburg i. B, 204 pp.

Wolffhügel K 1936. Fimbriariinae (Cestodes). Zeit Infekt 49: 257-291.

Woodall PF 1977. Cloacotaenia megalops (Cestoda, Hymenolepididae) in the redbilled teal. Ostrich 48 : 1-4. 